\title{
Senior High School Students' Mathematical Problem Solving Of Three-Variable Linear Equation System
}

\author{
Abdul Nu'man Asok ${ }^{1}$, A Hasanah ${ }^{2}$ \\ 1,2Mathematics Education, Universitas Pendidikan Indonesia, Indonesia \\ 1abdnumana@upi.edu,2aanhasanah@upi.edu
}

\begin{abstract}
Article History:

Received : 21-01-2021

Revised : 01-04-2021

Accepted : 03-04-2021

Online : 17-04-2021

Keyword:

Mathematical problem solving;

Three-variable linear equation systems; Qualitative.

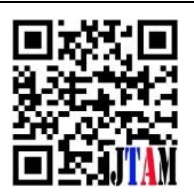

The aim of this research is to find the difficulties of students in solving word problems in the three-variable linear equation systems subject. Before they took a mathematical problem-solving exam, the learners were given reinforcement of prerequisite knowledge of the intended subject. The problem-solving test indicators used in this study were taken from Polya's problem-solving steps consisting of (1) recognizing the question, (2) making a plan for problem-solving (developing a plan), (3) implementing the plan for problem-solving, and (4) looking back. The research method used in this study was a qualitative descriptive. The subject in this study was 15 students who were 10 th graders of senior high school. The data were obtained from a student performance who took mathematical problems solving test. The result obtained from this study can be seen from the number of students whose achievement indicators formulate a plan of $49.6 \%$, achievement in completing plans $14.1 \%$, and achievement in checking solutions $2.2 \%$. However, the indicators of understanding the problem area in the good category, namely $80 \%$. The result of this study showed that the students were only able to solve the word problems for understanding the problem (good category) and devising the plan steps (mediocre category), whereas they got difficulties in solving the word problems in carrying out the plan and looking back (low category).
\end{abstract}

\section{doi Crossref}

https://doi.org/10.31764/itam.v5i1.3929

\section{(c) (1) (2)}

This is an open access article under the CC-BY-SA license

\section{A. INTRODUCTION}

Mathematics subjects are subjects that are given at every level of education from basic education. But in reality, mathematics is often considered a difficult subject to understand (Karso, 2019). According to the general public's opinion, one of the subjects that are considered difficult at the primary and secondary education levels in mathematics. This is because mathematics deals with abstract ideas and concepts (Herawati et al., 2010).

According Depdiknas (2006), learning mathematics has the goal of making students have the ability (1) To understand mathematical concepts, to clarify the link between concepts and to apply concepts or algorithms in problem-solving in a versatile, precise, successful and precise manner. (2) Using reasoning on patterns and properties, making generalizations of mathematical manipulations, compiling proof, or describing mathematical ideas and claims. (3) Address cases concerning the ability to understand problems, develop mathematical models, solve models, and interpret the solutions that have been obtained. (4) Expressing ideas in order to explain the situation or problem through symbols, charts, graphs, or other media. (5) Having an attitude of appreciating the value of mathematics in life, namely having an interest in learning mathematics, enthusiasm, concentration and motivation, as well as being resilient and 
confident in solving problems. This is focused on the learning goals set by the National Council of Teachers of Mathematics(NCTM, 2000)such as learning to interact, learning to reason, learning to solve problems, learning to relate ideas, and learning to represent ideas.Not much different from the 2013 curriculum, which contains the goal of emphasizing the modern pedagogical dimension for learning using a scientific (scientific) approach where the activities carried out to make learning meaningful, namely asking, trying, observing, reasoning, presenting, and creating in mathematics learning (Kemdikbud, 2013). Therefore, to educate students to be able to identify and solve issues they experience, learning must be created (Balım, 2009)

In learning mathematics so that it is easy for students to understand, it is hoped that mathematical abilities can be mastered by students which are useful for facing challenges in the era of globalization. These abilities include the ability to solve the mathematical problems which everyone wants to solve the problems of life and face the industrial revolution(Sani, 2014). The ability to solve mathematical problems for Indonesian students can still be said below. According to the 2015 Program for International Student Assessment (PISA) report, Indonesia is in position 63 out of 70 countries, which means that it is ranked 8th from the bottom and this is very concerning for the mathematical ability of students with an average score of 386. While the international average score is 490, which means that Indonesia's average score is still below the international average score(OECD, 2016). In addition, a survey from the 2015 Trend in International Mathematics and Science Study (TIMSS) resulted in Indonesia being ranked 6th from below, which means that Indonesia is in position 45 out of 50 countries with an average score obtained of 397 where the international average score is 500 . This means that Indonesia's average score is still far below the international average score (Mullis et al., 2012).

The primary aim of mathematics learning is to improve different kinds of ability to solve complex mathematical issues. The role of problem-solving in school mathematics is discussed (Stanic \& Kilpatrick, 1989) and demonstrates the rich history of the subject. Mathematics is synonymous with problem-solving - creating word problems, making patterns, analyzing numbers, designing geometries of construction, evidence theorems, etc.

Theoretically, "problem-solving" is usually defined as an effort to achieve some result when there is no established method to achieve it (for people trying to achieve that result)(Schoenfeld, 2014). The core theoretical argument in MPS (Mathematical Problem Solving), described by (Schoenfeld, 1989), states that there are four categories of problem-solving activities that need to be done to analyze the success or failure of students in problem-solving efforts, which include: (1) Individual awareness; (2) The use by individuals of problem-solving methods, known as heuristic strategies; (3) Individual monitoring and self-regulation (aspects of metacognition); and (4) Individual systems of belief (about themselves, about mathematics, about problemsolving) and the interactions of students with their mathematical backgrounds.

The mathematical problem-solving ability of students can be described as the ability of students to understand the problem, to prepare a strategy, to introduce the completion strategy, and to check back later to solve the problem by other means (Kuzle, 2013). Fehr (1953) state that a destination, the destination restrictions for individuals, and the individual's acceptance of the intent must be to solve the issue. What matters to one student does not matter to another, either because there are no limits or because targets are not recognized. (Schoenfeld, 2014) also illustrates that it is often relative to the person to define a problem. According to Suratmi \& Purnami (2017), the problem-solving abilities that humans must have at school age (students) include the ability of students to overcome any problems related to their education including problems in learning activities. One of the fields of study or subjects in schools that require problem-solving skills in mathematics. 
Problem-solving is very important in learning mathematics because problem-solving is important in improving students' higher-order thinking skills to explore the knowledge and skills they already have to solve problems that students rarely encounter. The use of mathematical problem-solving abilities that are by the problem can make mathematical ideas/ideas more concrete and help students to solve complex problems that are simpler. Problem-solving abilities can provide students fluency in building concepts and thinking mathematically and to have a strong understanding of the problem. Therefore, the ability to solve mathematical problems needs to be owned by students because it can make it easier for students to build a concept and think mathematically. This is certainly something to be worried about amidst being left behind in the science and technology field compared to other countries.

Beigie (2008) also expressed the importance of problem-solving, stating that students will learn to deepen their comprehension of mathematics by problem-solving by focusing on carefully chosen problems using the application of mathematics to contextual problems. Development of the capacity to solve mathematical problems in order to equip students to think objectively, analytically, systematically, critically and creatively.

If there is an awareness of the significance of taking an action but can not immediately fulfill it, a situation is called a problem (Ernest et al., 2016). Problems in mathematics present in the form of a question. These concerns can come from inside mathematics itself and can also come from real life (Foshay \& Kirkley, 2003), which includes mathematical facts and cultural environments. If students are ready to have a mathematical problem solving technique, then the question is no longer a question, but an exercise (Schoenfeld, 2014). The mathematical problem-solving abilities of students are still restricted in Indonesia. Results of teacher interviews indicate that problems in math words are very difficult. It was also found that mathematics is not preferred by many students because mathematics is too complex for these students. Similarly, the poor mathematical problem solving capacity of students (Simamora et al., 2017) while making observations at Pagaran Senior High School. The results of interviews with school teachers showed that mathematics is a topic that most students find less appealing. The results of observations by giving diagnostic tests to Pagaran Senior High School's tenth graders, with tests in the form of explanations to explain the ability of students to solve math problems, obtained the same information on the problem-solving abilities of other students, were very low.

The material of the system of three-variable linear equations is very closely related to problems in everyday life and is often encountered and experienced by students. Therefore, this paper aims to describe students 'mathematical problem-solving abilities in solving threevariable linear equation system problems and the causes of students' difficulties in solving these problems at each problem-solving step based on Polya's steps. There are 4 stages of problem-solving according to Polya (2004), namely: (1) Understanding the problem. Understanding the problem means seeing the issue at hand and in what state. Students need to decide and define what knowledge is known from the problem at this point, what to look for and inquire about the problem in their language, and repeat it; (2) Devising a plan. Creating a solution plan leads to the preparation of a mathematical model and the selection of strategies that will be used, making estimates and reducing things that are not directly related or simplifying the problem. Therefore, at this stage, students can build a mathematical model of the problem and define the strategies and approaches that will be used to solve the problem; (3) Carrying out the plan. Carrying out a settlement plan means implementing a plan that has been prepared to solve a problem. So, the plans that have been drawn up and the strategies and methods that students have chosen in the previous stage will be implemented at this stage; (4) Looking back. Re-checking the results of the solution means that students look back at the solutions or results obtained from the problem-solving steps so that there are no errors in the answers that have been written. From some explanation above problems, the author aims to 
describe students 'mathematical problem-solving abilities in solving three-variable linear equation system problems and the causes of students' difficulties in solving these problems.

\section{B. METHODS}

The method used in this study is a qualitative descriptive case study approach so that through this method and approach it is revealed the causes of student errors in solving mathematical problem-solving problems. The subjects used in the study consisted of 15 students of class X IPA in a high school in Bandung Regency, while the object observed was the results of student work related to students' problem-solving abilities on the topic of SPLTV. Before being given a problem-solving ability test, they were given reinforcement of the prerequisite material related to the topic of SPLTV.

The data used in this study were obtained from the results of a written test (essay) consisting of five questions and the results of the interviews. The measurement/assessment for the five written test questions was adopted from the problem-solving ability assessment sheet used by (Akbar et al., 2018), where the assessment sheet refers to Polya's four stages of problem-solving.

The interviews carried out were unstructured direct communication. However, communication with students is still carried out by paying attention to aspects that are by the data that has been collected. This direct communication is carried out to find out more deeply about the causes of difficulties in solving problems experienced by students in solving problems on student worksheets. Students who are selected to be interviewed directly are students who have different abilities (heterogeneous) in their initial mathematical abilities. The teacher divides the initial ability groups into three categories, namely students who have high abilities, moderate abilities, and low abilities seen from the average daily tests of the students. The average score for students in the high category is 86-100, the medium category is 70-85 and the low category is less than 70 . Of the three categories, some of the students who had difficulty solving the story questions were the fewest and the most selected to be interviewed. In this study, two high-ability students, two medium-ability students, and two low-ability students were taken. Then the data obtained is analyzed to conclude.

\section{RESULT AND DISCUSSION}

From the data, the results of this study are in the form of student learning outcomes who collect data using instruments in the form of essay test questions as many as 5 questions. The following is the data on the results of the mathematical problem-solving ability test which is presented in Table 1.

Table 1. Score indicators of mathematical problem-solving abilities

\begin{tabular}{ccccccccccc}
\hline \multirow{2}{*}{ No } & Code & \multicolumn{8}{c}{ Score Indicator question } \\
\cline { 2 - 12 } & & Problem 1 & \multicolumn{2}{c}{ Problem 2 } & \multicolumn{2}{c}{ Problem 3 } & \multicolumn{2}{c}{ Problem 4 } & \multicolumn{2}{c}{ Problem 5 } \\
\cline { 2 - 12 } & Ind 1 & Ind 1 & Ind 2 & Ind 2 & Ind 3 & Ind 2 & Ind 3 & Ind 3 & Ind 4 \\
\hline 1 & S1 & 3 & 3 & 3 & 0 & 0 & 1 & 0 & 0 & 0 \\
\hline 2 & $\mathrm{~S} 2$ & 1 & 0 & 0 & 0 & 0 & 1 & 0 & 0 & 0 \\
\hline 3 & $\mathrm{~S} 3$ & 2 & 3 & 3 & 0 & 0 & 3 & 0 & 1 & 0 \\
\hline 4 & $\mathrm{~S} 4$ & 3 & 3 & 3 & 1 & 0 & 3 & 3 & 1 & 0 \\
\hline 5 & $\mathrm{~S} 5$ & 3 & 3 & 3 & 0 & 0 & 1 & 0 & 0 & 0 \\
\hline 6 & $\mathrm{~S} 6$ & 3 & 3 & 0 & 0 & 0 & 3 & 0 & 0 & 0 \\
\hline 7 & $\mathrm{~S} 7$ & 1 & 3 & 1 & 0 & 0 & 1 & 0 & 1 & 0 \\
\hline 8 & $\mathrm{~S} 8$ & 2 & 3 & 3 & 3 & 0 & 3 & 0 & 3 & 1 \\
\hline 9 & $\mathrm{~S} 9$ & 1 & 1 & 0 & 1 & 0 & 0 & 0 & 1 & 0 \\
\hline
\end{tabular}




\begin{tabular}{lllllllllll}
\hline 10 & $\mathrm{~S} 10$ & 1 & 3 & 0 & 1 & 0 & 1 & 0 & 3 & 0 \\
\hline 11 & $\mathrm{~S} 11$ & 3 & 3 & 3 & 3 & 0 & 1 & 0 & 3 & 0 \\
\hline 12 & $\mathrm{~S} 12$ & 3 & 3 & 3 & 1 & 0 & 1 & 0 & 0 & 0 \\
\hline 13 & $\mathrm{~S} 13$ & 1 & 3 & 0 & 1 & 0 & 1 & 0 & 0 & 0 \\
\hline 14 & $\mathrm{~S} 14$ & 3 & 3 & 3 & 3 & 0 & 3 & 0 & 3 & 0 \\
\hline 15 & $\mathrm{~S} 15$ & 2 & 3 & 3 & 1 & 0 & 1 & 0 & 0 & 0 \\
\hline
\end{tabular}

Table 2. Percentage of problem-solving ability.

\begin{tabular}{ccccc}
\hline $\begin{array}{c}\text { Problem Solving } \\
\text { Indicator }\end{array}$ & $\begin{array}{c}\text { Student } \\
\text { Scores }\end{array}$ & Total & Percentage & Category \\
\hline Understanding Problem & 72 & 90 & $80 \%$ & Good \\
\hline Planning & 67 & 135 & $49,6 \%$ & Enough \\
\hline Performing the Plan & 19 & 135 & $14,1 \%$ & Very Less \\
\hline Looking Back & 1 & 45 & $2,2 \%$ & Very Less \\
\hline
\end{tabular}

The following shows some examples of student answers given test questions.

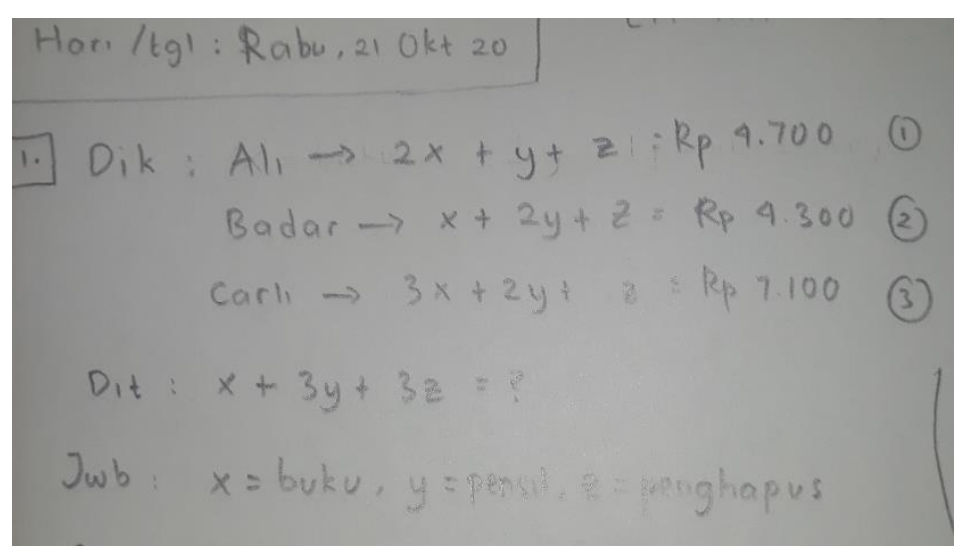

Figure 1. Student answer number 1

In Figure 1 there is indicator 1 (Understanding Problem) where on average students can complete mathematical modeling on SPLTV material.

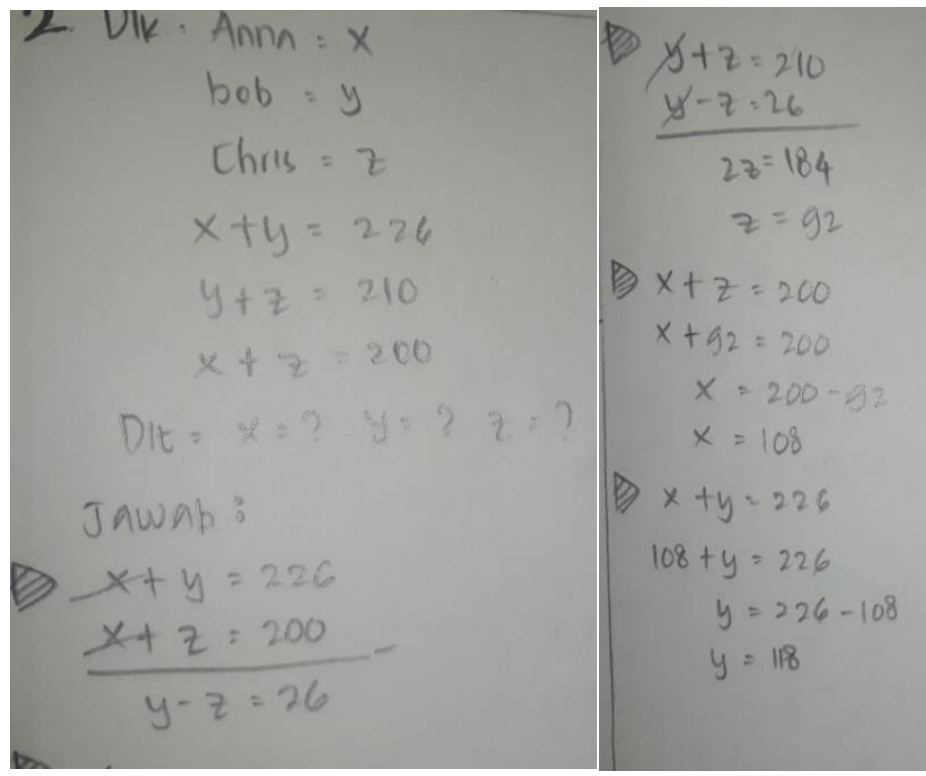

Figure 2. Student answer number 2 
In Figure 2. The answers to question number 2 have indicators 1 and 2 where on average students can understand the problem, identify known elements, ask questions, and make mathematical models.

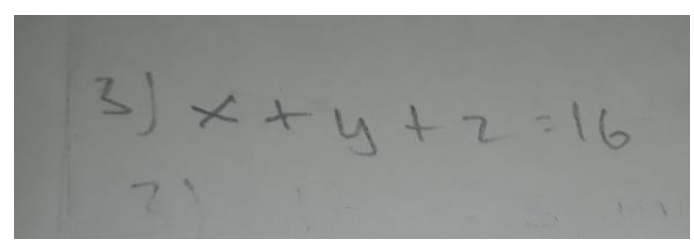

Figure 3. Student answer number 3

In Figure 3. One student's answer to question number 3.There are indicators 3 and 4 where the average student is only able to make a mathematical model.

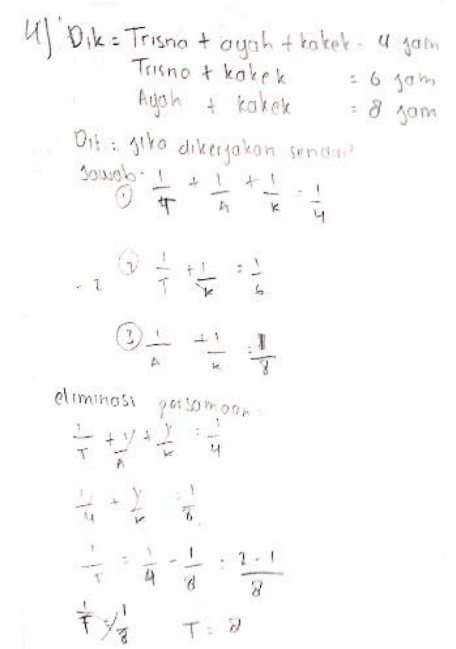

Figure 4. Student answer number 4

In Figure 4. Response from one student to question number 4. Indicators 2 and 3 exist where students can find alternatives to answer the questions on average.

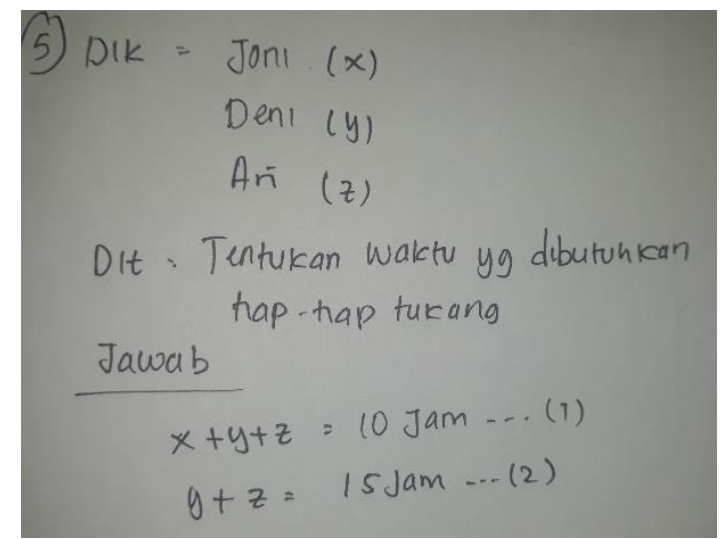

Figure 5. Student's answer number 5

In Figure 5. There are indicators 3 and 4 for one student's response (S12) to question number 5. Students can create mathematical models that are incorrect.

Meanwhile, based on the results of the direct interviews, the information found in the questions was not written by any students, as it was known to write down their linear equations, what was the question in the question. Students often solve problems directly because students think writing down the completion steps is not too important. After all, it is a waste of time. Students 
also often do not write about what they have to do at each completion stage, most students are still confused in preparing the completion steps. The errors in planning are caused because students do not know the completion strategy plan correctly. Students are not able to plan because students are not used to and immediately work on the questions without making plans in advance with sentences, other than that students have difficulty entering data in the formulas that have been written down, and students are not careful in the calculations they do. Meanwhile, the students' mistakes in indicator 4 (checking the solutions obtained) were caused by the students not thinking they needed to double-check because they were sure that the answer was correct. Besides, in checking the answers students are not accustomed to using systematic steps on the worksheets used. These errors are also consistent with the findings of the study carried out. (Hadi, 2018) that in general students do not have habits of mind to act carefully or make definite steps in making strategies even students generally give up easily when facing failure in executing the strategy so that they stop looking for other strategies when the previous strategic plan failed to be executed.

\section{CONCLUSION AND SUGGESTIONS}

Based on the results and discussion above, it can be concluded that the cause of the low achievement of the indicators of mathematical problem solving ability that students get is because some students are not able to plan, students are not used to it and immediately work on the questions without making plans in advance with sentences, other than that students have difficulty in making plans. enter data in the formula that has been written, and students are less careful in the calculations that are carried out. It can be seen in table 2 that the students' mathematical problem solving abilities are included in the sufficient category on the indicators of planning problems and low on the indicators of solving problems and checking This can be seen from the number of students who have achieved the achievement indicators of preparing plans $49.6 \%$, the achievement of completing plans $14,1 \%$ and the achievement in checking solutions is $2.2 \%$. However, the indicators of understanding the problem are in a good category, namely $80 \%$.

Therefore, researchers suggest that students are more often given contextual problems to be solved by identifying the variables that are arranged into the correct mathematical model so that their mathematical problem-solving abilities will increase optimally. Apart from that, it is necessary to have habits of mind systematically, carefully, and thoroughly in solving problems.

\section{REFERENCES}

Akbar, P., Hamid, A., Bernard, M., \& Sugandi, A. I. (2018). Analisis kemampuan pemecahan masalah dan disposisi matematik siswa kelas xi sma putra juang dalam materi peluang. Jurnal Cendekia: Jurnal Pendidikan Matematika, 2(1), 144-153.

Balım, A. G. (2009). The Effects of Discovery Learning on Students' Success and Inquiry Learning Skills. Eurasian Journal of Educational Research (EJER), 35.

Beigie, D. (2008). Integrating content to create problem-solving opportunities. Mathematics Teaching in the Middle School, 13(6), 352-360.

Depdiknas. (2006). Kurikulum tingkat satuan pendidikan (KTSP).

Ernest, P., Skovsmose, O., Paul van Bendegem, J., Bicudo, M., Miarka, R., Kvasz, L., \& Moeller, R. (2016). The philosophy of mathematics education. Springer Nature.

Fehr, H. F. (1953). The learning of mathematics: Its theory and practice (Vol. 21). National Council of Teachers of Mathematics.

Foshay, R., \& Kirkley, J. (2003). Principles for teaching problem solving. Technical Paper, 4.

Hadi, Samsul Herman, Tatang Hasanah, A. A. N. (2018). Students'difficulties In Solving 


\section{Mathematical Problems.}

Herawati, O. D. P., Siroj, R., \& Basir, D. (2010). Pengaruh pembelajaran problem posing terhadap kemampuan pemahaman konsep matematika siswa kelas xi ipa sma negeri 6 palembang. Jurnal Pendidikan Matematika, 4(1).

Karso. (2019). Pembelajaran Matematika di SD. In Pendidikan Matematika I (pp. 1-66).

Kemdikbud. (2013). Peraturan Menteri Pendidikan dan Kebudayaan Nomor 69 Tahun 2013 Tentang Kerangka Dasar dan Struktur Kurikulum Sekolah Menengah Atas/Madrasah Aliyah. Jakarta: Kemdikbud.

Kuzle, A. (2013). Patterns of metacognitive behavior during mathematics problem-solving in a dynamic geometry environment. International Electronic Journal of Mathematics Education, 8(1), 20-40.

Mullis, I. V. S., Martin, M. O., Foy, P., \& Arora, A. (2012). TIMSS 2011 international results in mathematics. TIMSS \& PIRLS International Study Center Chestnut Hill, MA.

NCTM. (2000). Principles and standards for school mathematics (Vol. 1). National Council of Teachers of.

OECD, P. (2016). Results (Volume I): Excellence and equity in education. Paris: OECD Publishing.

Polya, G. (2004). How to solve it: A new aspect of mathematical method (Vol. 85). Princeton university press.

Sani, R. A. (2014). Pembelajaran saintifik untuk implementasi kurikulum 2013. bumi aksara.

Schoenfeld, A. H. (1989). Teaching mathematical thinking and problem solving. Toward the Thinking Curriculum: Current Cognitive Research, 83-103.

Schoenfeld, A. H. (2014). Mathematical problem solving. Elsevier.

Simamora, S. J., Simamora, R. E., \& Sinaga, B. (2017). Application of problem based learning to increase students' problem solving ability on geometry in class X SMA Negeri 1 Pagaran. International Journal of Sciences: Basic and Applied Research (IJSBAR), 36(2), 234-251.

Stanic, G., \& Kilpatrick, J. (1989). Historical perspectives on problem solving in the mathematics curriculum. The Teaching and Assessing of Mathematical Problem Solving, 3, 1-22.

Suratmi, S., \& Purnami, A. S. (2017). Pengaruh Strategi Metakognitif Terhadap Kemampuan Pemecahan Masalah Matematika Ditinjau Dari Persepsi Siswa Terhadap Pelajaran Matematika. UNION: Jurnal Ilmiah Pendidikan Matematika, 5(2). 